\section{SAT0447 PREVALENCE OF RADIOGRAPHIC SACROILIITIS IN PATIENTS WITH PSORIATIC ARTHRITIS AND THE CLINICAL, ANALYTICAL AND DEMOGRAPHIC FACTORS ASSOCIATED TO ITS APPEARANCE}

C. López-Medina ${ }^{1,2}$, S. León-Idougourram ${ }^{2}$, M.D. López-Montilla ${ }^{1,2}$

L. Bautista-Aguilar ${ }^{1,2}$, L. Ladehesa-Pineda ${ }^{1,2}$, E. Collantes-Estévez ${ }^{1,2},{ }^{1}$ Hospital Universitario Reina Sofía de Córdobal Imibic; ${ }^{2}$ Universidad de Córdoba,

Córdoba, Spain

Background: To date, published studies suggest that a significant proportion of patients with Psoriatic Arthritis (PsA) present asymptomatic sacroiliitis; that is to say, an inflammatory back pain (IBP) absence. This fact could result in the underdiagnosis of axial involvement in these patients (1).

Objectives: To evaluate the prevalence of radiographic sacroilitis in patients with PsA and to determine its association with clinical, analytical and demographic factors.

Methods: A cross-sectional, observational, and unicentre study in which clinical, analytical and demographic data from 359 patients belonging to a PsA monographic consultation were analyzed. All patients met the CASPAR criteria. The presence of sacroilititis in the sacroiliac $\mathrm{x}$-ray image was used as a dependent variable, formerly evaluated by a trained Rheumatologist. Likewise, independent variables related to arthropathy, cutaneous involvement and sociodemographic characteristics of the patients were used as well. A descriptive analysis and two logistic regressions (univariate and multivariate), were performed to associate radiographic sacroiliitis to different covariates.

Results: Out of the 359 patients, 214 (59.6\%) were men with a mean time of PsA evolution of $10.05 \pm 11.6$ years. The $x$-ray image performed showed sacroilitis in 127 patients $(35.4 \%)$. Univariate analysis showed that radiographic sacroilitis is related $(p<0.05)$ to gender (men), psoriasic paternal family history, IBP, positive HLA-B27 antigen and psoriatic cutaneous involvement greater than $25 \%$. The multivariate analysis showed that radiographic sacroiliitis in these patients is predominantly associated to the presence of IBP, the positive HLA-B27 antigen and gender (men). However, sacroilititis is not not associated to the onset age of PsA $(p>0.05)$.

Univariate logistic regression

\begin{tabular}{lcccc}
\hline & $\begin{array}{c}\text { Sacroilitis } \\
\mathrm{n}=127(\mathrm{n} \%)\end{array}$ & $\begin{array}{c}\text { No Sacroiliitis } \\
\mathrm{n}=232(\mathrm{n} \%)\end{array}$ & OR (Cl 95\%) & p-value \\
\hline Sex (men) & $94(74.0)$ & $120(51.7)$ & $2.6(1.6-4.2)$ & $<0.001$ \\
Psoriasis duration, mean (SD) & $12.6(9.2)$ & $10.8(0.2)$ & $1.0(0.9-1.0)$ & 0.082 \\
PsA duration, mean (SD) & $5.5(5.9)$ & $4.5(6.3)$ & $1.0(1.0-1.0)$ & 0.041 \\
Onset age of PsA $\leq 45$ years & $76(59.8)$ & $131(56.6)$ & $1.1(0.7-1.7)$ & 0.536 \\
Family history of Psoriasis - None & $70(56.5)$ & $150(65.8)$ & Reference & \\
- Paternal & $29(23.4)$ & $35(15.4)$ & $1.7(1.0-3.1)$ & 0.048 \\
- Maternal & $25(20.2)$ & $43(18.9)$ & $1.2(0.7-2.2)$ & par 0.449 \\
IBP & $93(73.2)$ & $22(9.5)$ & $26.1(14.9-47.0)$ & $<0.001$ \\
HLA-B27 + & $22(17.5)$ & $11(4.8)$ & $4.1(1.9-9.0)$ & $<0.001$ \\
Psoriasis extension - $<10 \%$ & $177(76.6)$ & $78(61.9)$ & Reference & \\
- 10-25\% & $21(16.7)$ & $21(16.7)$ & $1.5(0.8-2.8)$ & 0.170 \\
$->25 \%$ & $23(10.0)$ & $27(21.4)$ & $2.6(1.4-4.9)$ & 0.002 \\
\hline
\end{tabular}

Conclusions: The prevalence of radiographic sacroilitis in our population is $35.4 \%$, higher than in other series due to the fact that the sacroiliac $x$-ray images were performed on all patients, regardless of the clinic. The radiographic sacroilititis in patients with PsA is related to the presence of IBP, HLA-B27 antigen and gender. However, the time of evolution of arthropathy and the onset age of PsA are not related to sacroiliac radiographic involvement.

\section{References:}

[1] Jadon DR, Sengupta R, Nightingale A, et al. Axial Disease in Psoriatic Arthritis study: defining the clinical and radiographic phenotype of psoriatic spondyloarthritis. Ann Rheum Dis 2016;0:1-7.

Disclosure of Interest: None declared

DOI: 10.1136/annrheumdis-2017-eular.3572

\section{SAT0448 APREMILAST TREATMENT AND LONG-TERM (UP TO 156 WEEKS) IMPROVEMENTS IN DACTYLITIS AND ENTHESITIS IN PATIENTS WITH PSORIATIC ARTHRITIS: ANALYSIS OF A LARGE DATABASE OF THE PHASE III CLINICAL DEVELOPMENT PROGRAM}

D.D. Gladman ${ }^{1}$, A. Kavanaugh ${ }^{2}$, J.J. Gomez-Reino ${ }^{3}$, J. Wollenhaupt ${ }^{4}$, M. Cutolo ${ }^{5}$, G. Schett ${ }^{6}$, E. Lespessailles ${ }^{7}$, M. Mcllraith ${ }^{8}, \mathrm{C} \mathrm{Hu}^{8}$, C.J. Edwards ${ }^{9}$, C.A. Birbara ${ }^{10}$, P.J. Mease ${ }^{11}$. ${ }^{1}$ Toronto Western Hospital, Toronto, Canada; ${ }^{2}$ University of California, San Diego, School of Medicine, la Jolla, United States; ${ }^{3}$ Hospital Clínico Universitario, Santiago, Spain; ${ }^{4}$ Schön Klinik Hamburg Eilbek, Hamburg, Germany; ${ }^{5}$ University of Genova, Genova, Italy; ${ }^{6}$ University of Erlangen-Nuremberg, Erlangen, Germany; ${ }^{7}$ University of Orléans, Orléans, France; ${ }^{8}$ Celgene Corporation, Summit, United States; ${ }^{9}$ University Hospital Southampton, Southampton, United Kingdom; ${ }^{10}$ University of Massachusetts Medical School, Worcester; ${ }^{11}$ Swedish Medical Center and University of Washington School of Medicine, Seattle, United States

Background: Dactylitis and enthesitis, hallmark features of psoriatic arthritis (PsA), may be difficult to manage. PALACE 1, 2, and 3 compared the efficacy and safety of apremilast (APR) with placebo (PBO) in patients (pts) with active PsA despite prior conventional DMARDs and/or biologics.

Objectives: Report the impact of long-term APR $30 \mathrm{mg}$ BID (APR30) treatment on dactylitis and enthesitis in pts with active PsA.

Methods: Pts were randomized (1:1:1) to PBO, APR30, or APR $20 \mathrm{mg}$ BID (APR20) stratified by baseline (BL) DMARD use (yes/no). After the 24-wk PBOcontrolled phase, all pts received APR30 or APR20 and could enroll in long-term follow-up. Data for pts entering the study with pre-existing dactylitis or enthesitis were pooled across PALACE 1-3, as prespecified, to allow for robust analysis. Dactylitis count (number of digits [hands/feet] with dactylitis present $[0=$ absence, 1=presence]; range: $0-20$ ) was used to assess dactylitis improvement. Enthesitis was evaluated based on MASES (range: $0-13$ ), indicating the number of painful entheses out of 13 enthesis sites. Wk 24 analyses used LOCF for missing values and data for early escape pts; Wks 52 and 156 used data as observed.

Results: Among pts with dactylitis $(n=610)$ or enthesitis $(n=915)$ at $B L$ and $\geq 1$ post-BL value, BL mean dactylitis counts ranged from 3.2 to 3.4 and MASES ranged from 4.4 to 4.8 . At Wk 24 , mean change in dactylitis count was -1.8 (APR30) vs -1.3 (PBO) $(P=0.0097)$; more APR30 pts achieved a dactylitis count of 0 vs PBO pts (Table). Mean change in MASES was -1.3 (APR30) vs -0.9 (PBO) $(P=0.0194)$; more APR30 pts achieved a MASES of 0 vs PBO pts. Significant effect on enthesitis was confirmed in the PSA-006 (ACTIVE) study of APR in pts with a maximum of 1 previous DMARD treatment, in which the Gladman Enthesitis Index was used, focusing on more peripheral sites of activity: significant effect for APR vs PBO was seen as early as Wk 2, and at Wk 24 , mean changes were -1.5 vs $-0.5(P=0.0032$, MMRM). Sustained improvements in dactylitis and enthesitis severity were seen in APR pts at Wk 156 in PALACE 1-3 (Table): for dactylitis, $79.6 \%$ achieved a count of 0 and the mean percent change was $-83.6 \%$; for MASES, $55.0 \%$ of APR pts achieved a score of 0 and the mean percent change was $-65.2 \%$.

\begin{tabular}{|c|c|c|c|c|}
\hline & \multicolumn{2}{|c|}{ Wk 24} & Wk 52 & Wk 156 \\
\hline Dactylitis Count ${ }^{*}$ & $\begin{array}{c}\text { PBO } \\
\mathrm{n}=205\end{array}$ & $\begin{array}{l}\text { APR30 } \\
n=221\end{array}$ & $\begin{array}{l}\text { APR30 } \\
n=249\end{array}$ & $\begin{array}{l}\text { APR30 } \\
n=181\end{array}$ \\
\hline $\mathrm{BL}$, mean & 3.3 & 3.2 & 3.4 & 3.4 \\
\hline Mean change from $\mathrm{BL}$ & -1.3 & $-1.8 \mid$ & -2.5 & -3.0 \\
\hline Mean $\%$ change from $B L$ & -38.2 & -48.6 & -67.9 & -83.6 \\
\hline Median $\%$ change from BL & -66.7 & -79.3 & -100.0 & -100.0 \\
\hline Pts achieving score of $0, \%$ & 39.0 & 46.2 & 67.5 & 79.6 \\
\hline MASES $S^{5}$ & $\begin{array}{c}\text { PBO } \\
\mathrm{n}=311\end{array}$ & $\begin{array}{l}\text { APR30 } \\
\mathrm{n}=327\end{array}$ & $\begin{array}{l}\text { APR30 } \\
\mathrm{n}=377\end{array}$ & $\begin{array}{c}\text { APR30 } \\
\mathrm{n}=278\end{array}$ \\
\hline $\mathrm{BL}$, mean & 4.8 & 4.4 & 4.4 & 4.2 \\
\hline Mean change from $\mathrm{BL}$ & -0.9 & $-1.3^{\ddagger}$ & -2.0 & -2.7 \\
\hline Mean $\%$ change from BL & -7.0 & $-23.6^{\ddagger}$ & -43.5 & -65.2 \\
\hline Median \% change from BL & -21.1 & $-50.0 \neq$ & -66.7 & -100.0 \\
\hline Pts achieving score of $0, \%$ & 22.5 & 27.5 & 37.7 & 55.0 \\
\hline \multicolumn{5}{|c|}{$\begin{array}{l}\text { The } n \text { at Wk } 24 \text { represents pts with a BL value }>0 \text {. The } n \text { at Wk } 52 \text { and Wk } 156 \text { represents the number of } \\
\text { pts taking APR, regardless of when treatment started (BL, Wk } 16 \text {, or Wk 24), with a BL value }>0 \text { and a } \\
\text { value at Wk } 52 \text { or Wk } 156 \text {. }\end{array}$} \\
\hline \multicolumn{5}{|c|}{$\begin{array}{l}\text { "Dactylitis count is the sum of all scores }(0=\text { absence of dactylitis; } 1=\text { presence of dactylitis) from each of } \\
\text { the } 20 \text { digits. SMASES ranges from } 0 \text { to } 13 \text {, with } 0 \text { indicating no pain at any assessed enthesis and } 13 \\
\text { indicating pain at all assessed entheses. } ₹ P<0.05 \text { vs PBO. IP<0.01 vs PBO. } \\
\text { PBO=placebo; APR } 30=\text { apremilast } 30 \mathrm{mg} \text { BID; BL=baseline; pts=patients; MASES=Maastricht Ankylosing } \\
\text { Spondylitis Enthesitis Score. }\end{array}$} \\
\hline
\end{tabular}

Conclusions: The majority of pts (63\%) in PALACE 1-3 had active enthesitis and $42 \%$ had dactylitis at BL. APR30 demonstrated early and long-term benefit (up to 156 wks) in treating dactylitis and enthesitis, including resolution of BL disease in many pts.

Disclosure of Interest: D. Gladman Grant/research support from: AbbVie, Amgen, BMS, Celgene Corporation, Janssen, Novartis, Pfizer, UCB, Consultant for: AbbVie, Amgen, BMS, Celgene Corporation, Janssen, Novartis, Pfizer, UCB, A. Kavanaugh Grant/research support from: Abbott, Amgen, AstraZeneca, BMS, Celgene Corporation, Centocor-Janssen, Pfizer, Roche, UCB, J. Gomez-Reino Grant/research support from: Roche and Schering-Plough, Consultant for: BMS, Pfizer, Roche, Schering-Plough, UCB, J. Wollenhaupt Grant/research support from: Abbott, BMS, MSD, Pfizer, UCB, Consultant for: Abbott, BMS, MSD, Pfizer, UCB, M. Cutolo Grant/research support from: Actelion, BMS, SanofiAventis, Consultant for: Actelion, BMS, Sanofi-Aventis, G. Schett Grant/research support from: Abbott, Celgene Corporation, Roche, UCB, Consultant for: Abbott, Celgene Corporation, Roche, UCB, E. Lespessailles Grant/research support from: Amgen, Eli Lilly, Novartis, Servier, Speakers bureau: Amgen, Eli Lilly, Novartis, Servier, M. Mcllraith Employee of: Celgene Corporation, C. Hu Employee of: Celgene Corporation, C. Edwards Grant/research support from: Celgene Corporation, Pfizer, Roche, Samsung, Consultant for: Celgene Corporation, Pfizer, Roche, Samsung, Speakers bureau: Abbott, GSK, Pfizer, Roche, C. Birbara Grant/research support from: Amgen, BMS, Incyte, Eli Lilly, Merck, Pfizer, P. Mease Grant/research support from: Abbott, Amgen, Biogen Idec, BMS, Celgene Corporation, Genentech, Janssen, Eli Lilly, Novartis, Pfizer, Roche, UCB, Consultant for: Abbott, Amgen, Biogen Idec, BMS, Celgene Corporation, Genentech, Janssen, Eli Lilly, Novartis, Pfizer, Roche, UCB, Speakers bureau: Abbott, Amgen, Biogen Idec, BMS, Genentech, Janssen, Eli Lilly, Pfizer, UCB DOI: 10.1136/annrheumdis-2017-eular.3821 